\title{
ANTARCTIC WEDDELL SEA ODP SITE 696 PLEISTOCENE- PLIOCENE DIATOMS
}

MARK LAPAN, Colgate University

Research Advisor: Amy Leventer

\section{INTRODUCTION}

\section{Pleistocene-Pliocene Antarctic Glacial History}

As the impacts of climate change become clearer, scientists look to the earth's climatic history to place modern warming into a longer term perspective. In particular, scientists look to past warm periods to measure and model such important environmental parameters as sea level, atmospheric circulation, ice accumulation and atmospheric chemistry. The mid-Pliocene, from 4.5-3.3 million years ago is considered a potential analog for future climate given its many similarities to the modern world - with a similar geography of continents and oceans, intensity of solar radiation reaching the earth, and critically, carbon dioxide levels that are similarly high (Naish et al., 2009; Pollard and DeConto, 2009; Federov et al., 2013; Golledge et al., 2017). The Pleistocene interglacial periods, especially some of which appear to have been warmer than the present interglacial, for example Marine Isotope Stage 31 (Scherer et al., 2008) and Marine Isotope Stage 11 (Raymo and Mitrovica, 2012) are also ideal candidates to explore the consequences of a warmer world.

This project examines the Pleistocene using diatoms, plankton with silica tests, in a 10 -m sediment core $(2 \mathrm{H})$ recovered from the Weddell Sea, from ODP Leg 113, Site 696 (see Figure 1). Diatoms are excellent as climatic indicators, given their sensitivity to a suite of environmental factors, including temperature, salinity, light levels, nutrient content, and the presence or absence of sea ice (Armand et al. 2005). For this study, the extent of seasonal sea ice cover was considered to be a critical factor controlling the concentration of diatom valves in sea floor sediments. As Burckle and Cirilli (1987) noted, for example, heavy sea ice cover restricts light penetration, and decreases primary productivity. Consequently, downward flux of diatoms is minimal during times of cooler climate and associated sea ice expansion. In contrast, warmer intervals with decreased sea ice cover, contain more biosiliceous sediments. The goal of this study was to evaluate diatom assemblage and abundance patterns in silica-rich sediments from the Jane Basin, at the northern tip of the Antarctic Peninsula, in order to understand past warm periods in this region.

\section{International Ocean Discovery Program}

The Ocean Drilling Program (ODP) and its successor, the International Ocean Discovery Program (IODP), is a scientific ocean drilling program that collects ocean floor geological data that are used to advance our understanding of a wide range of questions regarding Earth's history and dynamics. ODP Leg 113 took place in 1987 and was focused on the climatic and oceanographic evolution of the Weddell Sea. For this specific project, sediments from Hole 696A were selected for analysis, given shipboard biostratigraphic data that suggested the recovery of Pleistocene interglacial material (Gersonde and Burckle, 1990). Hole 696A is located at 61O50.945'S, 42055.984'W. The total depth of the hole was 106 meters and $58.3 \mathrm{~m}$ were recovered (Barker et al., 1988). 


\section{METHODS}

Core 696A-2H was run through a multi-track sensor at the IODP repository at Texas A\&M University in College Station. Two downcore measurements, magnetic susceptibility and bulk density, were made on the archive half of Core 686A-2H to guide sampling. Dropstones, $>2 \mathrm{~mm}$ were removed before the measurements were made. The core had shrunk and had numerous cracks, which disrupted the continuous measurements.

\section{Magnetic Susceptibility}

Magnetic Susceptibility (MS) is a measure of the relative proportion of magnetic material within a given sample. In sediments from the Southern Ocean, MS often indicated the relative contribution of terrigenous material versus biogenic material to the sediment (Leventer et al., 1996). This is because most biogenic input is in the form of biogenic silica and organic carbon, which do not contribute to MS. Measurements were taken at $0.1 \mathrm{~cm}$ intervals. These data (Fig 1) were used to determine sampling intervals for diatom identification, since this project focused on addressing the past periods of ocean warmth, which were most likely to have been recorded as intervals of low MS, due to greater biogenic production in open waters.

\section{Bulk Density}

Bulk density measurements were also collected via the non-destructive tool of the multi-track sensor. These data, also collected at $0.1 \mathrm{~cm}$ intervals are illustrated in Figure 1.

\section{Diatom Sampling, Processing and Identification}

Samples for qualitative and quantitative diatom analyses were selected based on the MS record, with low MS intervals presumed to be richer in diatomaceous material. Samples were dried at $<50$ degrees $\mathrm{C}$, followed by weighing out a mass between 20-50 milligrams. Samples then were placed in glass vials on a warming tray set to 50 degrees C. Samples were cleaned using $10 \%$ hydrogen peroxide to remove organic material; after several days on the warming tray, samples were then placed into settling chambers and quantitative slides were made according to the method from Warnock and Scherer (2014). Microscopy was completed using an Olympus BX40 microscope. Observations were made at a magnification of 1000x. Microphotographs were taken using a Lumenara camera system. A total of 17 samples were taken (Fig 1). Of those 17 samples, 11 species were found that could be used to help date the core. Although the initial intent of the study was to find absolute and relative abundance of the diatom species observed, this result was not reached due to various obstacles. Thus, the end goal of the project was more preliminary taxonomy and slide creation for further quantitative work in the future.

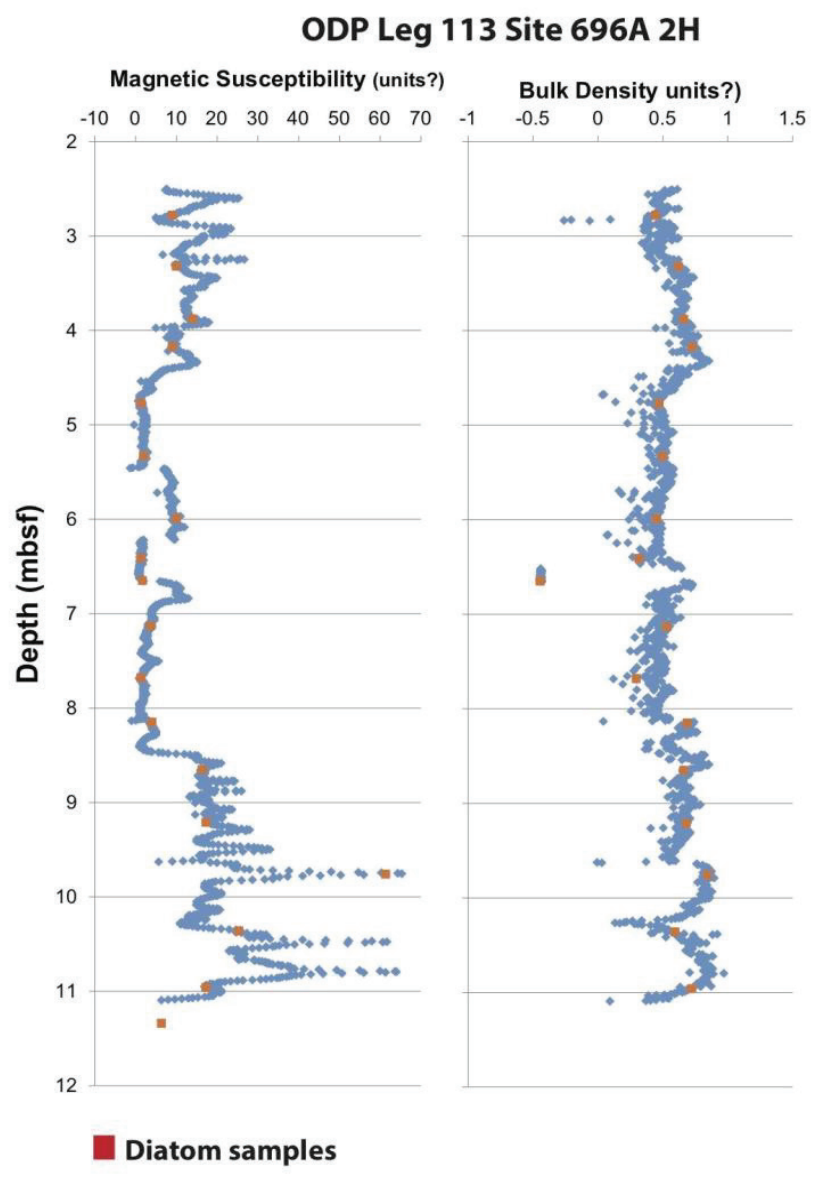

Figure 1. Magnetic Susceptibility and Bulk Density with location of samples examined for diatoms. 


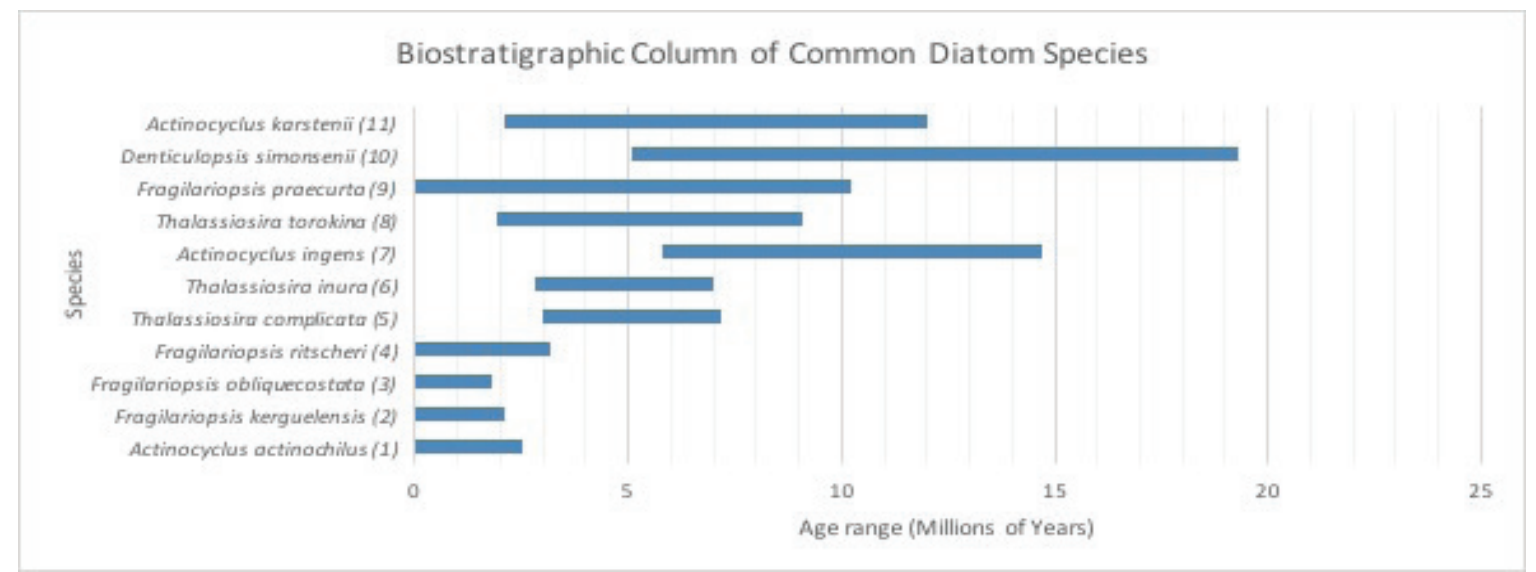

Figure 2. Biostratigraphic column of commonly observed diatom species.

\section{RESULTS}

\section{Diatom Images}

Diatom images were compiled using Photoshop to alter the coloration so that the images would match in color tone to account for differences in lighting when the photos were taken. The images taken and edited in Photoshop were then put in pdf format to create a taxonomic guide, this could be used as a template for counting the number of a specific species of diatom in the future (Fig. 3).

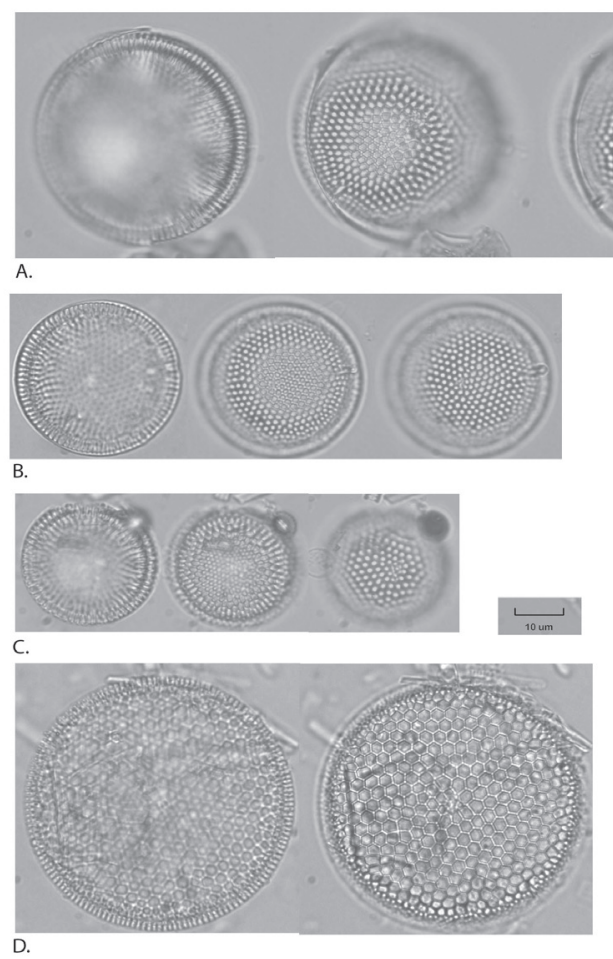

Figure 3. Images of Diatom species A-D: Thalassiosira torokina.

\section{Biostratigraphic Position}

From Cody et al. (2008), we can create a time sequence for when a majority of diatom species lived during the Pliocene and Pleistocene. Figure 2 illustrates a focused version of this graph with respect to the diatoms observed in this core. Using this information we can estimate the time during which the sediments in this core were deposited.

\section{DISCUSSION}

One goal of this project was to study the paleoceanographic record of warm intervals of Earth's history, based on diatoms from ODP Leg 113 Site 696. The first step toward accomplishing this goal was to understand the stratigraphic framework for the samples selected for study, by comparing their diatom assemblage with stratigraphic zonations for the Southern Ocean (Cody et al., 2008). Among the first to contribute to this field of study were Weaver and Gombos (1981), who proposed the Neogene (last 24 m.y.a.) diatom zonation by summarizing species into easily recognizable and broad geographic distributions. Gersonde and Burckle (1990), more specifically examined Neogene sediments from Leg 113, and given the excellent core recovery, were able to revise earlier zonation schemes. They addressed several critical and unresolved points, including the use of Last appearance datums (LADs), and the previous use of several poorly described species as biostratigraphic markers which led to incorrect age assignments. For example, Miocene zones were not directly tied to the magnetic time scale, and long (4 m.y.) zone ranges needed to be 
refined. These issues were addressed by initial studies at Site 696. Gersonde and Burckle (1990) presented 16 diatom zones that were described along with several stratigraphically useful diatom datums of late early Miocene to Pleistocene age. This work stands as the foundation for the research conducted during this project.

Based on the diatom biostratigraphy (Gersonde and Burckle 1990, Gersonde et al. 1990), this core which was located at depth of 0-550 meters below sea floor, dates back to the early to late Pliocene. This new work aimed to re-address the timing of biosiliceous sections of $696 \mathrm{~A}-2 \mathrm{H}$, following upon the earlier findings.

A brief taxonomic guide to species observed in this core section (Fig 3) documents the microscopy, and provides some preliminary guidance. However, the findings of this new work remain inconclusive, due to the presence of many unidentified species, and a large range in morphology within individual species. In addition, some stratigraphically significant species here were not identified in Gersonde and Burckle (1990).

For example, in the samples studied, Thalassiosira torokina was found to be abundant, yet Gersonde and Burckle (1990) do not record this species from the same section of Core 2H-696A. This may be due to a wide range in the morphology of this species. Larger Thalassiosira torokina are more three dimensional for example, while smaller specimens of Thalassiosira torokina are flatter, making it easier to have the entire valve in focus in a single view. As presented in Gersonde and Burckle (1990) we also observed Thalassiosira inura. Figure 2 is a graphical represen-tation of the ages that species observed.

\section{Conclusions and Challenges with this study}

The identification and counting of diatoms from these samples was challenging for several reasons. First, this researcher was new to the field of micropaleontology, so learning the fundamentals of diatom taxonomy was more time intensive than initially anticipated. In addition, the nomenclature of diatom species has evolved over time, primarily through detailed study of DSDP, ODP and IODP materials. Consequently, the names of many species have changed over time; for this reason, species identification required a thorough acquaintance with the large body of taxonomic literature.
Overall, development of a biostratigraphic and paleoceanographic story based on samples from Leg 113 will require continued effort.

Moving forward from this study, the next step is to complete both absolute and relative diatom abundance counts. This would enable us to develop a biostratigraphic framework for the core, and to reconstruct changes in the oceanic environment over time. In addition, comparison of diatom abundance data and physical parameters, such as magnetic susceptibility, could provide information on changes in paleoproductivity that could be extrapolated beyond the scope of individual micropaleontologic analysis.

\section{ACKNOWLEDGEMENTS}

This material is based upon work supported by the Keck Geology Consortium and the National Science Foundation under Grant No. 1659322.

\section{REFERENCES}

Armand, L.K., Xavier, C., Romero, O., and Pichon, J.J., (2005). The biogeography of major diatom taxa in Southern Ocean sediments: 1. Sea ice related species, Palaeogeography, Palaeoclimatology, Palaeoecology 223 93-126. Barker, P.F., Kennett, J. P., et al., (1980). Proc. ODP, Init. Repts., 113: College Station, TX (Ocean Drilling Program).

Burckle, L.H. and Cirilli, J., (1987). Origin of diatom ooze belt in the Southern Ocean: implications for paleoceanography and paleoclimatology, Micropaleontology 33, 82-86.

Cody, R.D. , Levy, R.H., Harwood, D.M., Sadler, P.M., (2008). Thinking outside the zone: Highresolution quantitative diatom biochronology for the Antarctic Neogene.Palaeogeography, Palaeoclimatology, Palaeoecology 260 92-121. Fedorov, A.V., Brierley, C. M., Lawrence, K. T., Liu, Z., Dekens, P.S., Ravelo, A.C. (2013) Patterns and Mechanisms of early Pliocene warmth. Nature, 496 43-49. doi:10.1038/ nature12003. Gersonde, R.(1990) Taxonomy and morphostructure of Neogene diatoms from the Southern Ocean, ODP Leg 113. Proceedings of the Ocean Drilling Program, Scientific Results, 113 791-802. 
Gersonde, R. and Burckle, L.H. (1990) Neogene Diatom Biostratigraphy of ODP Leg 113, Weddell Sea (Antarctic Ocean). Proceeding of the Ocean Drilling Program, Scientific Results, 1137 61-789.

Golledge, N.R., Thomas, Z.A., Levy, R.H., Gasson, E.G., Naish, T.R., McKay, R.M., Kowalewski, D.E. and Fogwill, C.J., (2017). Antarctic climate and ice-sheet configuration during the early Pliocene interglacial at 4.23 Ma. Climate of the Past 13(7): 959-975.

Naish, T., Powell, R., Levy, R., Wilson, G., Scherer, R.,Talarico, F., Krissek, L., Niessen, F., Pompilio, M., Wilson, T., Carter, L., Deconto, R.,Huybers, P., McKay, R., Pollard, D., Ross, J., Winter, D., Barrett, P., Browne, G., Cody, R., Cowan, E., Crampton, J., Dunbar, G., Dunbar, N., Florindo, F., Gebhardt, C., Graham, I., Hannah, M., Hansaraj, D., Harwood, D., Helling, D., Henrys, S., Hinnov, L., Kuhn, G., Kyle, P., Läufer, A., Maffioli, P., Magens, D., Mandernack, K., McIntosh W., Millan, C., Morin, R., Ohneiser, C., Paulsen, T., Persico, D., Raine, I., Reed, J., Riesselman, C., Sagnotti, L., Schmitt, D., Sjunneskog, C., Strong, P., Taviani, S., Vogel, S., Wilch, T., Williams, T. (2009) Obliquity-paced Pliocene West Antarctic ice sheet oscillations, Nature, 458(7236):322-8. doi: 10.1038/ nature 07867.

Pollard, D. and DeConto, R. M. (2009) Modelling West Antarctic ice sheet growth and collapse through the past five million years, Nature, 458 , 329-332.

Raymo, M. E., and Mitrovica, J.X., 2012, Collapse of polar ice sheets during the stage 11 interglacial, Nature, doi:10.1038/nature10891.

Scherer, R. P., Bohaty, S., Dunbar, R., Esper, O., Flores, J., Gersonde, R., Harwood, D., Roberts, A. and Taviani, M. Antarctic records of precession-paced insolation-driven warming during early Pleistocene Marine Isotope Stage 31. Geophysical Research Letters, 35, doi:10.1029/2007GL032254.

Warnock, J. P., Scherer, R. P. (2014) A Revised Method for Determining the Absolute Abundance of Diatoms. Journal of Paleolimnology, Doi: 10.1007/s10933-014-9808-0
Weaver, F.M., and Gombos, A.M.(1981) Southern high latitude diatom biostratigraphy, DSDP: Decade of Progress: Society of Economic Palaeontologists and Mineralogists Special Publication, 32, 445-470. 